\title{
The STEM Career Education Intervention Module Through Career Exploration Activities
}

\author{
Lenny Shafinaz Md Yusoff* \\ Universiti Kebangsaan Malaysia \\ P99926@siswa.ukm.edu.my*
}

\author{
Salleh Bin Amat \\ Universiti Kebangsaan Malaysia \\ sallehba@ukm.edu.my
}

\author{
Mohd. Izwan Mahmud \\ Universiti Kebangsaan Malaysia \\ izwan@ukm.edu.my
}

\begin{abstract}
The goal of achieving a ratio of $60: 40$ for science students to arts students has yet to be reached, even though the initiative began 52 years back. The Science, Technology, Engineering and Maths (STEM) Career Education Intervention Module serves as a method of educational intervention of secondary school students' career paths, and to encourage them to be more interested in careers within the STEM field. This module was created to help students who may not be fully aware of the potentials of pursuing a career path in the field of STEM, and it will also serve as a source of information for parents so they may further understand their child's abilities, and also to educators in honing the students' talents and potential. Through intervention activities and career explorations, students will obtain knowledge, decision-making skills, an increased selfefficacy, and further experiences in their careers will propel them to excel academically and also in their future careers.
\end{abstract}

Keywords-STEM, career path, talent and potential, selfefficacy, career exploration

\section{INTRODUCTION}

Students must be exposed to information and knowledge on careers from the time they are in primary school. Choosing an interest, a career path and setting career goals is imperative to every student in ascertaining their interests and passion. The students' inclinations that must be determined are their desires and goals, which will be their keys to succeed in life and carry out the responsibility of seeking further knowledge. Comprehending one's academic path based on one's interests and skills are very effective in determining the course of study that they will choose [1]. Parents must play a role in giving their children exposure in career education as early as possible at home, whether it is through the medium of reading materials, toys or by bringing their children to places that offer information on careers.

The guidance and Counselling teacher of Sekolah Kebangsaan (SK) Putrajaya Presit 9(2), a high prestige school, Mrs Mazli Sham Abdullah stresses that exposure to career information from the primary school level will increase the comprehension and self-awareness of the students, in regards to the career field they will choose to enter in future [2]. The widespread practice of career education guidance must continue to the secondary education level through various outreach programmes, such as through career seminars, career workshops, career talks, career interventions, career visitations, the sharing of career experiences and also through career exhibitions that are held outside of or within the school vicinity; by inviting various governmental and nongovernmental agencies to share information and their expertise in their respective career fields. Currently, the career education in the fields of science, technology, engineering and maths (STEM) are very much needed in order to face the fourth industrial revolution challenge, to keep students informed on the relevant information needed for careers, as well as their career paths, especially for secondary school students. These students in particular must be exposed to the proper knowledge of careers in the field of STEM, as early as possible.

The widespread practice of conducting career education in regards to the fields of science, technology, engineering and math (STEM) is highly encouraged to be carried out at the secondary school level through exploration activities via the STEM Career Education Intervention Module. Mohd Izwan Mahmud [3] has listed seven studies done in regards to the career education intervention through modules after his indepth readings and research on the structured career programmes at the secondary school level, which are: the Career Planning Module, Integrated Career Development Module, Self-Promotion Programme, Career Exploration Programme, Career Discovery Module, Career Planning Workshop and the Career Awareness Module. He has also surmised that the aforementioned studies show that there is a positive effect on the students' career development [3].

Therefore, interventions done through this STEM career education module is hoped to give the needed exposure to students on their ambitions and careers, which is in line with the changes in future as they face the fourth industrial revolution. Lastly, it is hoped that this study will be impactful to the secondary school students and help them in increasing their knowledge in careers, identifying their talents and potential when deciding on a career path in future, as well as help the government reach their target of having a ratio of 60:40 for science students to arts students.

\section{Background of the Study}

McLeod, Scott and Karl Fisch's study in the World Economic Forum Report has predicted that $65 \%$ of children that are entering primary school education today will be working in jobs that are newly created, or jobs that do not exist yet in today's market, as a result of the fourth industrial revolution. The latest phenomenon in the field of Science, Technology, Engineering and Maths (STEM) show that even though 52 years have passed, the Ministry of Education's goal since 1967 of achieving a target ratio of 60:40 for science 
students to arts or social science students at the school level and higher education institution level has yet to materialise. This is proven through a statement given by the Examination Board in regards to the Sijil Pelajaran Malaysia (SPM) 2018 results, which was announced last March 2019, that showed a steep decline for a number of STEM-based subjects, the decreasing number of students in the STEM stream will cause implications to higher education institutions and skills training institutions, in terms of the production of skilled and semiskilled workers such as technicians, mathematicians, actuaries, systems analysts, graphic creators, researchers, engineers and also architects [4].

Recently, the Minister of Education, Dr Maszlee Malik stated that the number of students opting for science, technology, engineering and maths subjects decreases with each passing year, in his speech at the Bett Asian Leadership Summit and Expo 2019. Dr Maszlee also mentioned that even though the field of STEM plays a role that aligns closely with the creation of new occupations and the robust development of the digital industry, the talent offered in that particular field is worryingly low, because only $44 \%$ of Malaysian students took up the STEM stream in 2018 , as compared to the $49 \%$ of students in the year 2012. A few studies have shown that the lack of exposure on the application of science and maths in everyday life is also one of the reasons that there is a significant drop in students pursuing the STEM stream from 203391 students in 2012 to 167962 students in 2018, as stated by the Chief Executive Officer of the Academy of Science Malaysia, Hazami Habib to BERNAMA.

The Chairman of the National STEM Movement, Professor Datuk Dr. Noraini Idris also reported that the significant drop can be observed by the reduced number of science stream classes in schools, where there have been up to four or five classes previously, which has now dwindled to one or two classes in total; and this decreasing trend of students entering the STEM stream will cause implications to the capacity of professional staff, whom will contribute to the future development of the nation, whereby, the production of highly qualified engineers, scientists and doctors may not come to pass. Most recently, Salman Hamat Amir Abd Hamid , Muhammad Saufi Hassan and Mahaizura Abd Malik, through their writings in the MyMetro publication, stated that by the year 2020, it is estimated that 133 million types of occupations around the world will evolve into new occupations, whereas 75 million more will become obsolete, as a result of technological advancements. Their findings were obtained from The Future of Jobs Report 2018, as surmised by the World Economic Forum at their conference in Switzerland last year.

Even though Malaysia has yet to achieve the status of a developed nation that is dominated by the influence of the Fourth Industrial Revolution, the effects of the matter is already apparent, especially amongst those in the education sector, in working to produce the sufficient labor needed to meet the demands of the job market [5]. In conclusion, the issues that stem from the changes caused by the fourth industrial revolution is causing quite a large impact to the career education counselling services in schools which are lagging behind in meeting the demands of the $21^{\text {st }}$ century workforce. How much preparation can the career education in secondary schools supply to students, in ensuring they are well-equipped with the $21^{\text {st }}$ century knowledge and skills needed for the coming future?

\section{Purpose of the Study}

Based on the above discussions, this study aims to prepare a module for Career Education Intervention in the fields of science, technology, engineering and mathematics (STEM) for secondary school students in rural areas.

\section{Research Questions}

There are a few research questions that are highlighted in the current study. These questions are: 1) to identify the need for creating a career education module in the fields of science, technology, engineering and mathematics (STEM); 2) to identify the level of interests of students in the fields of science, technology, engineering and mathematics (STEM); 3) to measure the correlation between career knowledge and career interest in planning the student's career path in the fields of science, technology, engineering and mathematics (STEM); 4) to measure the effect of the STEM career education module towards students' career knowledge in the fields of science, technology, engineering and mathematics (STEM); 5) to measure the effect of the STEM career education module towards the students' career interests in the fields of science, technology, engineering and mathematics (STEM); and; 6) to determine the reliability of the STEM career education module.

\section{STATEMENT OF PROBLEM}

The 60:40 ratio (science : arts) policy has been practiced in the national education system since 1967 to this day, whereby the National Basis of Education (Dasar Pendidikan Kebangsaan), under Article 4.9 [6], states that secondary schools must reach the aforementioned ratio to ensure that the nation has human resources in the fields of science and technology, and $60 \%$ of the students should be in the science stream. The previous Deputy Minister of Education, during an interview at the House of Representatives stated that the Ministry of Education has carried out various strategies through the Malaysian Education Development Plan 20132025 to strengthen the Science, Technology, Engineering \& Math (STEM) subjects, in an effort to create more experts in these fields for the betterment of the nation. Thus, in the effort to fulfil the ratio of 60:40 (science : arts) students, the nation is in desperate need of students who are prepared to take on career paths in the STEM field.

Even so, the number of students entering the science stream in secondary schools has yet to achieve the goal ratio that was set back in 1967. According to statistics published by the Ministry of Education (MOE) from 1981 till 2010, the percentage of secondary school students who entered the science stream has never reached the 60:40 ratio. There is also a large disparity between students in urban and rural areas in the perspective of science and math education. The percentage of urban school students who followed the Physics, Chemistry, Biology and Additional Math subjects are always far higher, compared to their peers in rural schools. The examination results for the subjects of math and science at the PMR and SPM levels plainly show that urban school students 
perform substantially better than the rural school students. The government has amended existing policies, and introduced various policies and education plans, as well as taking various approaches, but the issue of having students who are interested to pursue the science and technical streams have yet to be solved in our educational system. The ratio of science students to arts students of (60:40) will still be out of reach if no proper effort is taken accordingly.

The statement above is supported by Ayob in Siti Hajar [7], whereby they found that students' interests towards science and math has further deteriorated, and that this is a global phenomenon. This is based on the report done by the Organization for Economic Cooperation and Development (OECD) in 2010, where they found a worrisome trend in the enrolment of students in fields such as Mathematics, Physics and Chemistry, whereby there is a decrease in the number of university graduates of about $30 \%$ to $50 \%$ in the past 8 to 10 years. Moreover, studies have already done by Syed Abd Hakim, Ghandiswari, TIMSS [8] have shown that there are various factors that affect the students' choice in choosing to pursue the science and technical stream or the arts stream when in secondary school, among which is the factor to do with the perception and worry of poor achievement results and the difficulty of mastering the concept of science, peer influence and parents who are unconducive towards science and math, as well as the assumption that the chances of furthering studies at the tertiary education level are lower for science stream students.

True to the aforementioned phenomenon, it is surmised that the decreasing number of students entering the science stream that continues to be more critical has birthed a new phenomenon in the world of education, that always had the goal of moving towards the direction of a developed country. Therefore, this study aims to develop the career module for secondary school students in rural areas, so they will have knowledge related to the fields of science and technology, increase their self efficacy, and at the same time, help the students choose suitable careers in the fields of STEM and TVET.

\section{RESULTS AND DISCUSSIONS}

\section{STEM}

STEM is the acronym for Science, Technology, Engineering and Maths. Even so, Mazlini [9] are of the opinion that STEM is a philosophy or a way of thinking whereby a few subjects, such as science, math, engineering and technology are integrated into a field of education that is thought to be more suitable and relevant to be taught in schools, as it emphasizes the aspects of practicality and reality. According to the opinions of experts in the field of early childhood education, the education of STEM should begin at an early age [9]. It is found that these previous studies show that the exposure of STEM in early childhood education can: (a) build a foundation for learning and development in the minds of children in the future; (b) help in developing critical thinking and reasoning skills; (c) increase their interests towards studying science and maths, as well as an interest in STEM-related careers; (d) develop curiosity, enquiry and investigative characteristics; and (e) give the children an extensive experience about the natural and manmade world around them [9].

Children that are growing in terms of intellectual capacity have the desire in seeking out new knowledge. This desire to seek out new knowledge should be guided through the proper methods, they also begin thinking about their careers in future when reaching adolescence and they need vocational guidance [10]. Suraidi Salim in Amla [11], stress that secondary school students in Malaysia are still not receiving sufficient information about their career aspirations. Relevant studies also found that the number of students whom selected an occupation that is suited to them is very low.

Information from the past few years have found that the interest of students in the STEM field is decreasing. Five decades have passed, and the 60:40 ratio has yet to be fulfilled. Moving on, previous researches have found that generally, the students' knowledge of things related to choosing a career is scarce and very limited, which shows that their level of awareness of careers is low, even though there is a fraction of students that have a high degree of awareness [11] further substantiates the MOE's statement in the Preliminary Report of the Malaysian Education Development Plan 2013-2025 (PPPM 2013-2015) stated above.

\section{Career Education}

Career path education should be made the main issue in the national education system, in order to face the challenges and job opportunities to face the fourth industrial revolution in Malaysia. An error in choosing a field of study in the next stage can affect one's future career [12]. This is proven through the Preliminary Report of the Malaysian Education Development Plan 2013-2025 (PPPM 2013-2015), which states that guidance and counselling teachers must help students plan their education paths and choose their career paths. However, it is found that guidance and counselling teachers play only a small role and are not prepared to guide students in planning their education and career paths.

Even though the guidance and counselling services have long existed in this country in the Daily School Management Division, the Ministry of Education has taken the initiative to publish the Buku Panduan Pelaksanaan Perkhidmatan Bimbingan dan Kaunseling di Sekolah Rendah dan Menengah in 2014 to replace the Buku Panduan Pelaksanaan Perkhidmatan Bimbingan dan Kaunseling di Sekolah Rendah dan Menengah Edisi 2009. Nonetheless, the students' career education is still found to be wholly lacking and is not satisfactory, especially in rural schools [10].

In an effort to face the challenge of career education industrial revolution 4.0, based on the discussion and results obtained from a study by Mohd Izwan Mahmud [13] as mentioned previously, it is found that the existing modules for career education need to be improved, in order to face the impending fourth industrial revolution, which will indirectly also demand for a change and transformation in the career education field in Malaysia, so that schools can prepare the students who will select a course of study that caters to industrial demands., analytical knowledge and problem solving skills. The newest developments in the fourth industrial revolution has created the need to put together a career education module that can birth students who are highly 
skilled, self-aware, who are aware of the future of global occupations, as well as aware of their interests clearly, and are able to adapt themselves to $21^{\text {st }}$ century jobs.

In their study ten years ago, Hussin and Zakuan [13] identified four issues that are related to the fulfilment of the 60:40 ratio of science to arts students, one of which is related to the interests and tendency of students to follow a course that is related to the fields of science and technology. A few past studies also proved that the problem of students not receiving sufficient career information stems from poor information management, incomplete information, outdated and hard to obtain due to there not being any system that is updated, widely spread and easily accessible. This matter is a challenge to students, job hunters and vocational counsellors when attempting to respond to the need for effective planning [11].

Based on the discussion above, it is seen that secondary school students are very much in need of career knowledge, guidance and proper skills and the correct methods in preparing them further for $21^{\text {st }}$ century careers. Amla and their fellow researchers also concluded that through career education, we will be able to help individuals obtain jobs and determine whether they like or dislike the job, as well as help these individuals develop more skills and knowledge related to that particular job [11]. Clearly, through career education, one can obtain the proper knowledge needed, as well as be able to make the appropriate preparations to pursue their dream jobs and aspirations.

Sidek in the Inaugural Lecture, titled The Application of Psychometric Exams in Guidance and Counselling of Careers, states that there are three individual problems related to careers, which are: (i) the individual are not self-aware of their interests, personality, worth and achievements, (ii) the individual is not aware of the working world, whereby they have insufficient career information, and (iii) the individual is unable to make a decision due to having many interests, are not clear of their interests, or have no interests whatsoever. According to Sidek, the best strategy in choosing a career is when someone is self-aware, aware of the working world and is able to adapt themselves with that particular job.

The American Government have also taken serious steps a few years ago, in improving their students' career knowledge, by introducing their national education policy, which is "No Child Left Behind". This Act included monetary support that was imperative in encouraging various parties to take the proper steps, including developing career potentials in the students who are showing a drop in potential, who are playing truant and who failed academically. These career education programmes have successfully increased students' motivation to learn, reduced dropping of potential and have also succeeded in encouraging students to keep learning. Moreover, there is also a fraction of students who are successful and interested to further their studies to the next level [11].

Based on discussions, it can be concluded that it is imperative that secondary school students are equipped with knowledge in STEM career education, which can be obtained through various approaches or suitable interventions to develop their interests to opt for STEM-related courses and to further propel themselves into the industry job market in future.

\section{CONCLUSIONS}

Various studies have been conducted that show that STEM is very effective in increasing the students' interests in science and mathematics, and their success in jobs that are STEMrelated [9]. The researchers hope that by 2025, a Career Module can be developed and be made as an intervention to STEM career education that will give an effective and interesting learning experience to secondary school students, as well as help guidance and counselling teachers play their part and are prepared to guide students in planning their career and education paths.

\section{REFERENCES}

[1] Halim Razali. 2019. Panduan Hala Tuju Akademik Dan Kerjaya Selepas SPM. Kuala Lumpur:Dewan Bahasa Dan Pustaka.

[2] Nas Norziela. (2017). "Memilih Kerjaya Pada Usia Muda". Atas Talian: $\quad$ https://www.pressreader.com/malaysia/berita-harianmalaysia/20171106/281956018055219

[3] Mohd Izwan Mahmud, Sidek Mohd Noah, Wan Marzuki Wan Ahmad. (2016). Modul Kesediaan Kerjaya Berdasarkan Teori Cognitive Information Processing (CIP). Jurnal Kurikulum \& Pengajaran Asia Pasifik. Bil.4, Isu 3.

[4] Mohd Feroz Abu Bakar. 2019. "Tarik Minat pelajar ambil bidang STEM". Atas Talian: https://www.bharian.com.my/rencana/komentar/2019/03/541214/tarik -minat-pelajar-ambil-bidang-stem

[5] Anonim. 2019. "Jumlah pelajar mengambil STEM kian Merosot". Atas Talian:

https://www.bharian.com.my/berita/pendidikan/2019/03/540193/juml ah-pelajar-mengambil-stem-kian-merosot

[6] Kementerian Pendidikan Malaysia. 2015. Pelan Pembangunan Pendidikan Malaysia 2013-2025. Percetakan Nasional Malaysia.

[7] Siti Hajar. (2013). Memacu pelan transformasi pendidikan : peranan IPTA dalam membantu meningkatkan kuantiti dan kualiti Pendidikan Aliran Sains dan Teknikal di Malaysia. In: Seminar Kebangsaan Kali ke-4 Majlis Dekan Pendidikan IPTA 2013 , 23-25 September 2013, Universiti Islam Antarabangsa Malaysia

[8] Fatin Aliah Phang, Mohd Salleh Abu, Mohammad Bilal Ali. 2012. "Faktor Penyumbang Kepada Kemerosotan Penyertaan Pelajar Dalam Aliran Sains: Satu Analisis Sorotan Tesis". Atas talian: https://www.academia.edu/3014026/Faktor_penyumbang_kepada_ke merosotan_penyertaan_pelajar_dalam_aliran_sains_satu_analisis_sor otan_tesis

[9] Mazlini Adnan, Aminah Ayob, Ong Eng Tek, Mohd Nasir Ibrahim, Noriah Ishak, Jameyah Sheriff . (2016). Memperkasa pembangunan modal insan Malaysia di peringkat kanakkanak: Kajian kebolehlaksanaan dan kebolehintegrasian pendidikan STEM dalam kurikulum PERMATA Negara. GEOGRAFIA OnlineTM Malaysian Journal of Society and Space 12 issue 1 (29 - 36).

[10] Shima Junn Willie, Abu Yazid Abu Bakar. 2019. Keperluan Khidmat Bimbingan dan Kaunseling Dalam Kalangan Pelajar Sekolah Menengah Luar Bandar:Satu Kajian Kes. Jurnal Dunia Pengurusan. Vol.1, No.1, 18-24.

[11] Amla Salleh, Zuria Mahmud, Ramlee Mustapha. (2008). Mengenal Potensi Kerjaya. Universiti Kebangsaan Malaysia.

[12] Nur Liyana Mohd Ibrahim, Mohammad Aziz Shah Mohamed Arip. 2014. Analisis Kesahan Kandungan Modul Penyesuaian Pemikiran Kerjaya (PPK) Berdasarkan Pendekatan Teori Cognitive Information Precessing (CIP). JPBU Vol.7, 52-67.

[13] Sufean Hussin, Nurliza Zakuan. 2009. Dasar Modal Insan 60:40 Dalam Sains \& Teknologi. Puchong:Tinta Publishers. 